Original Article

\title{
SELF-MEDICATION PRACTICE AMONG CONSUMERS IN SANA'A CITY
}

\author{
SAMI MOHAMMED ALBAWANI, YAHAYA BIN HASSAN*, NOORIZAN ABD-AZIZ, SHUBASHINI GNANASAN
}

Faculty of Pharmacy, Department of Pharmacy Practice, University Teknologi MARA, Malaysia

Email: profyahaya@gmail.com

Received: 11 May 2016 Revised and Accepted: 12 Aug 2016

\begin{abstract}
Objective: To determine the prevalence of self-medication practice and its associated risk factors in Sana'a City.

Methods: A cross-sectional descriptive study was carried out on consumers attending community pharmacies in Sana'a City. A self-administered questionnaire containing open-ended and closed-ended questions was developed and used for this study. Chi-square test and multiple logistic regressions were used in this study.

Results: A total of 400 consumers were involved in this study. The prevalence of self-medication in the past six months was found to be $90.7 \%$ ( $94.1 \%$ of females and $88.3 \%$ of males). In Multivariate analysis, chewing khat, smoking, availability of medical services near the residence and the perception about death due to self-medication were significant predictors of self-medication practice. Those who chewed khat were less likely to use self-medication compared to those who did not chew khat (OR=0.296, CI 95\% 0.100-0.882, p=0.029). Similar results showed that smokers were less likely to use self-medication compared to non-smokers (OR=0.429, CI 95\% 0.206-0.895, $p=0.024)$. It was also found that those who have medical services near their residence were more likely to use self-medication compared to those who do not have medical services near their residence $(\mathrm{OR}=3.022$, CI 95\% 1.384-6.596, $\mathrm{p}=0.006)$. Moreover, those who did not believe that self-medication leads to death were more likely to use self-medication compared to those who believed that self-medication may leads to death (OR=2.645, CI 95\% $1.232-5.681$, $\mathrm{p}=0.013)$.
\end{abstract}

Conclusion: Self-medication practice was high among consumers in Sana'a City. Chewing khat, smoking, availability of medical services near the residence and the respondent perception about the possibility of death due to self-medication was significantly associated with self-medication.

Keywords: Self-medication, Risk factors, Khat, Community pharmacies, Sana'a City

(C) 2016 The Authors. Published by Innovare Academic Sciences Pvt Ltd. This is an open access article under the CC BY license (http://creativecommons. org/licenses/by/4. 0/) DOI: http://dx.doi.org/10.22159/ijpps.2016v8i10.12748

\section{INTRODUCTION}

Self-medication is a common practice worldwide. It can be defined as the use of drugs to treat self-diagnosed disorders or symptoms, or the intermittent or continued use of a prescribed drug for a recurrent disease or symptoms. Self-medication, as one element of self-care, is the selection and use of medicines by individuals to treat self-recognized illnesses or symptoms [1]. It plays an important role in some developing and economically poor countries. However, it was found to be related to socio-economic factors, availability of medications, law, advertisement and lifestyle [2].

Self-medication is an important response to an illness that can be controlled in its early stage. Although negative implications have been suggested to it, the existence of its vital role was acknowledged by the World Health Organization [3] However, drug abuse can lead to serious side effects, toxicity, and drug interaction or could delay accurate diagnosis and treatment [4]. Moreover, there is a worldwide concern about the resistance of microorganisms toward antibiotics in people abusing oral antibiotics. Therefore, there is an urgent need to recognize and determine the risk factors associated with self-medication practice.

Many researchers have been studying self-medication practice all over the world and different studies showed different outcomes. In some studies, younger age groups were found to be more engaged in self-medication than older ones [5-7]. However, the association between self-medication and age was not found in other studies [8, 9]. Association between gender and self-medication was found [10, 11], but some studies revealed no association between them [8-12].

In Yemen, very few studies about self-medication were found in the literature. A study conducted in a private hospital in Yemen stated that antibiotics use in children without a medical prescription is alarmingly high, and intervention from health authorities was suggested [13]. In another study, irrational treatment of malaria was observed among households. Belief, experience, lack of confidence in health services and cost of treatment were the reasons for selfmedication as suggested by the researcher [14]. A study on the prevalence of self-medication in a city in Yemen was conducted, and misuse, and irrational overuse of drugs by patients were found [15]. The objective of this study was to determine the prevalence of selfmedication practice and its associated risk factors in Sana'a City.

\section{MATERIALS AND METHODS}

A cross-sectional descriptive study was carried out on consumers attending community pharmacies in Sana'a City. A self-administered questionnaire containing open-ended and closed-ended questions was developed and used for this study. The questionnaire was evaluated by five expert reviewers and pre-tested in a pilot study on a sample of 40 participants attending a community pharmacy in Sana'a City. The questionnaire was developed in English and then a bilingual expert was asked to translate the instrument from English to the Arabic language. Permission to carry out this study was obtained from UiTM Research Ethics Committee, the administration of health office and targeted community pharmacies in Sana'a City.

After describing the purpose of this study, written consent was obtained from each participant. Using a convenience sampling method, a total of 400 self-administered questionnaires were distributed to consumers attending 10 community pharmacies selected to represent all districts at Sana'a City. The questionnaire included questions about the sociodemographic characteristics of participants, type of medication used, symptoms or illness treated, reasons for self-medication practice, source of information or advice during self-medication practice and their perception about the safety of the medication.

All data obtained from the questionnaire were coded, entered and analyzed using SPSS statistical software version 21 [16]. Chi-square test was used to assess the association between the categorical variables and the use of self-medication. Multiple logistic regressions were used to identify predictors of self-medication practices among the population of the study. 


\section{RESULTS}

A total of 400 questionnaires were completed and collected, out of which 231 (57.8\%) were males, and 169 (42.2\%) were females. The mean age \pm SD of the respondents was $28.6 \pm 7.7$ (range 18-65). Table 1 shows the descriptive analysis of the variables. The majority were married (62.8\%), with a degree (64.3\%), non-smokers (77.2\%), khat chewers $(72.5 \%)$, without medical insurance $(85.7 \%)$, with low income (74.3\%) and have access to medical centers (83.3\%).

The prevalence of self-medication in the past six months was found to be $90.7 \%$ ( $94.1 \%$ of females and $88.3 \%$ of males).

Table 1: Descriptive analysis

\begin{tabular}{|c|c|c|}
\hline Variables & $\mathbf{N}$ & $\%$ \\
\hline \multicolumn{3}{|l|}{ Age } \\
\hline $18-39$ & 367 & 91.8 \\
\hline $40-59$ & 30 & 7.5 \\
\hline$\geq 60$ & 3 & 0.8 \\
\hline \multicolumn{3}{|l|}{ Gender } \\
\hline Male & 231 & 57.8 \\
\hline Female & 169 & 42.2 \\
\hline \multicolumn{3}{|l|}{ Marital status } \\
\hline Married & 251 & 62.8 \\
\hline Single & 149 & 37.2 \\
\hline \multicolumn{3}{|l|}{ Education Status } \\
\hline Primary & 44 & 11 \\
\hline Secondary & 75 & 18.7 \\
\hline Diploma & 24 & 6 \\
\hline Degree & 257 & 64.3 \\
\hline \multicolumn{3}{|l|}{ Employment } \\
\hline Employed & 130 & 32.4 \\
\hline Unemployed & 143 & 35.8 \\
\hline Student & 127 & 31.8 \\
\hline \multicolumn{3}{|l|}{ Income } \\
\hline$\leq 50,000$ Yemeni Riyals & 297 & 74.3 \\
\hline $51,000-100,000$ Yemeni Riyals & 58 & 14.5 \\
\hline$>100,000$ Yemeni Riyals & 45 & 11.2 \\
\hline \multicolumn{3}{|l|}{ Self-medication } \\
\hline Yes & 363 & 90.7 \\
\hline No & 37 & 9.3 \\
\hline \multicolumn{3}{|l|}{ Medical Insurance } \\
\hline Yes & 57 & 14.3 \\
\hline No & 343 & 85.7 \\
\hline \multicolumn{3}{|l|}{ Medical center } \\
\hline Yes & 333 & 83.3 \\
\hline No & 67 & 16.7 \\
\hline \multicolumn{3}{|l|}{ Chewing khat } \\
\hline Yes & 290 & 72.5 \\
\hline No & 110 & 27.5 \\
\hline \multicolumn{3}{|l|}{ Smoking } \\
\hline Yes & 91 & 22.8 \\
\hline No & 309 & 77.2 \\
\hline
\end{tabular}

Fig. 1 Show the most common drug used during self-medication. Drug commonly used were analgesics (90.1\%), antimicrobials (87.1\%), antipyretics (64.2\%), antacids (51.2\%), vitamins and minerals (50.7\%) and common cold (72.2\%) medications.

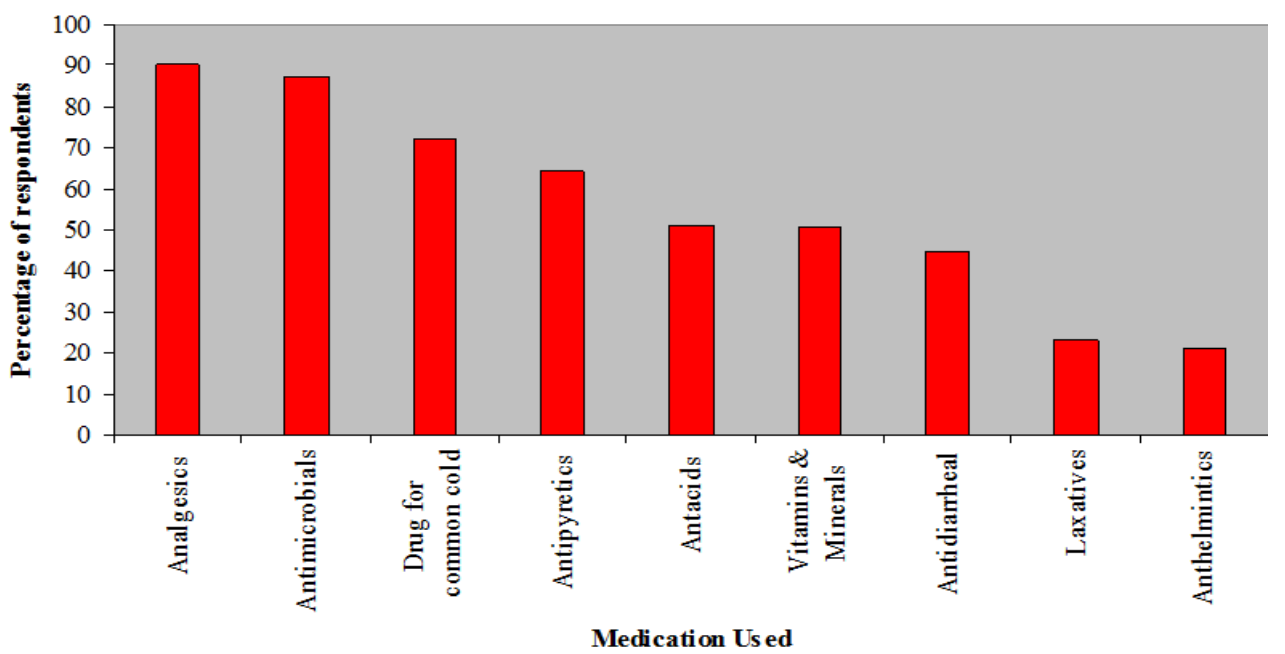

Fig. 1: Most common medication used during self-medication 
The majority of illness/symptoms which were treated during selfmedication were headache (78\%), common cold $(66.8 \%)$, fever
(60.5\%), cough (57.5\%), acidity/ulcer (46\%), constipation (20.5\%) and back pain (19.3\%) (fig. 2).

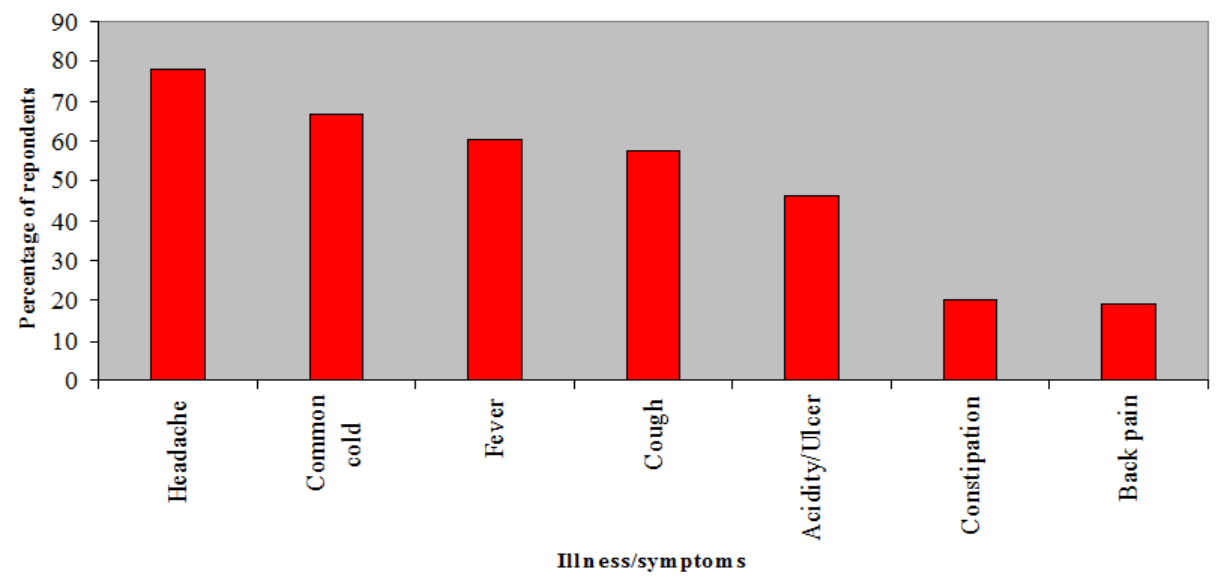

Fig. 2: Illness/symptoms treated during self-medication

Common reasons for self-medication can be seen in fig. 3. The high cost of physician consultation (92.3\%) was found to be the main reason for the respondents to practice self-medication. Other reasons like the case was not serious (65.6\%), and time consuming (30.6\%) were reported as well.

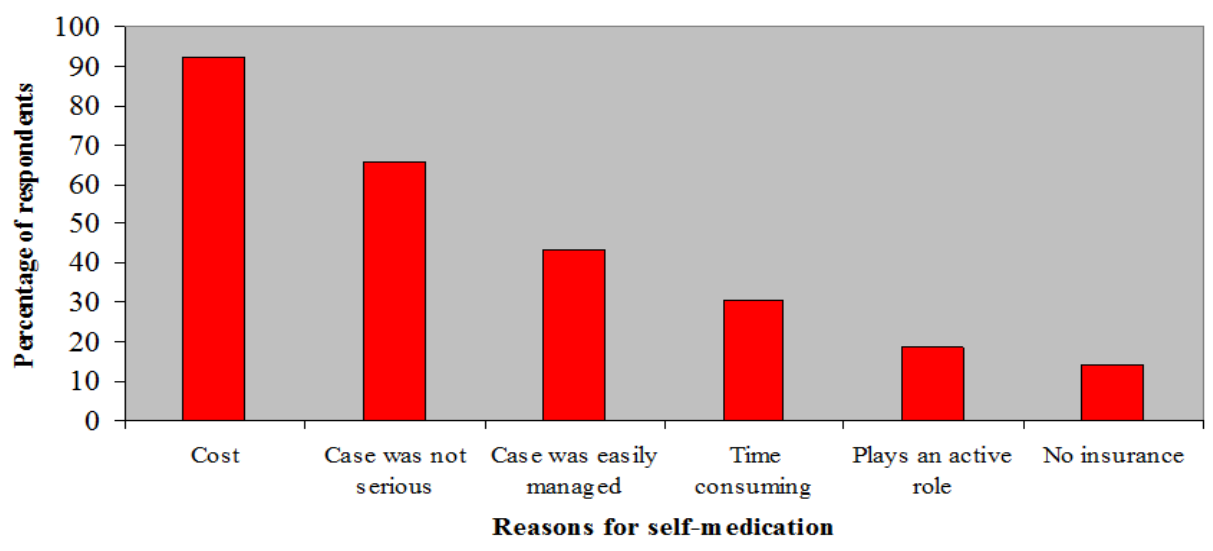

Fig. 3: Reasons for self-medication

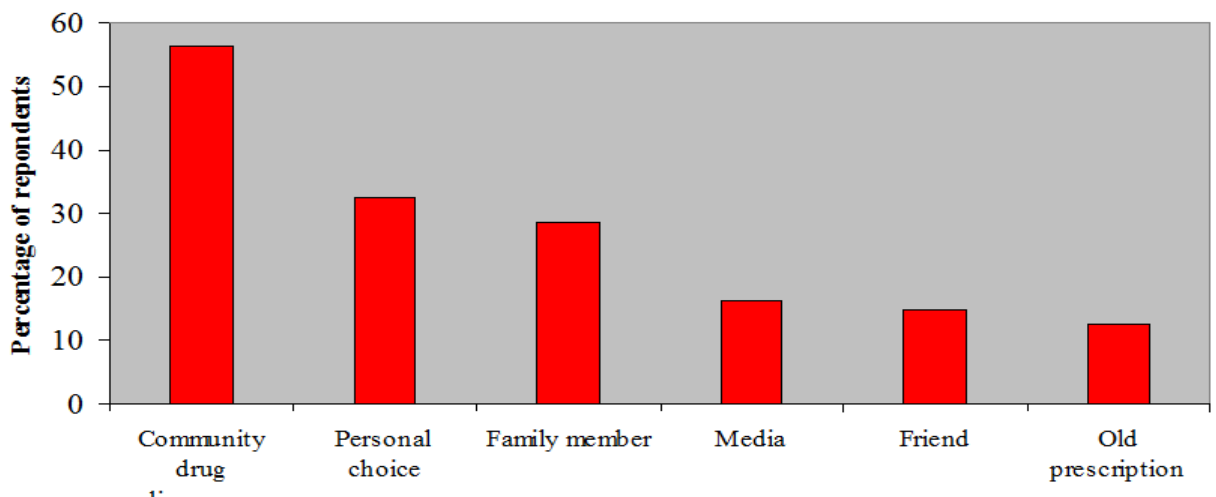

Sou rces of inform ation/advice for self-m edication

Fig. 4: Sources of information/advice for self-medication

Fig. 4 showed that the common source of information were the community drug dispensers (56.2\%) followed by family members $(28.7 \%)$ and then media (16.3\%).

The bivariate analysis was used to identify the risk factors associated with self-medication as shown in table 2 . It was found that factors like gender, chewing khat, smoking, availability of medical services near the residence, respondent perception about the complications due to self-medication and death due to selfmedication have an association with self-medication practice. However, only chewing khat, smoking, respondent perception about the complications due to self-medication and the availability of medical services near their residence were found to be significant predictors of self-medication practice (table 3). 
Table 2: Bivariate analysis (Chi square test)

\begin{tabular}{|c|c|c|c|c|c|c|c|}
\hline \multirow[t]{2}{*}{ Variables } & \multirow[b]{2}{*}{ Yes (\%) } & \multirow[b]{2}{*}{ No (\%) } & \multirow[b]{2}{*}{$\begin{array}{l}\text { Chi- } \\
\text { Square }\end{array}$} & \multirow[b]{2}{*}{$\begin{array}{l}\text { Odds } \\
\text { Ratio } \\
\end{array}$} & \multicolumn{3}{|c|}{ C. I 95\% } \\
\hline & & & & & Lower & Upper & Sig. \\
\hline \multicolumn{8}{|l|}{ Age } \\
\hline $18-39$ & $331(90.2)$ & $36(9.8)$ & 1.69 & & & & 0.429 \\
\hline $40-59$ & $29(96.7)$ & $1(3.3)$ & & & & & \\
\hline$\geq 60$ & $3(100.0)$ & $0(0.0)$ & & & & & \\
\hline \multicolumn{8}{|l|}{ Gender } \\
\hline Male & $204(88.3)$ & $27(11.7)$ & 3.87 & 0.475 & 0.223 & 1.011 & 0.049 \\
\hline Female & $159(94.1)$ & $10(5.9)$ & & & & & \\
\hline \multicolumn{8}{|l|}{ Material Status } \\
\hline Married & $225(89.6)$ & $26(10.4)$ & 0.99 & 0.690 & 0.330 & 1.440 & 0.321 \\
\hline Single & $138(92.6)$ & $11(7.4)$ & & & & & \\
\hline \multicolumn{8}{|l|}{ Educational Status } \\
\hline Primary & $40(90.9)$ & $4(9.1)$ & 2.94 & & & & 0.401 \\
\hline Secondary & 71 (94.7) & $4(5.3)$ & & & & & \\
\hline Diploma & $23(95.8)$ & $1(4.2)$ & & & & & \\
\hline Degree & $229(89.1)$ & $28(10.9)$ & & & & & \\
\hline \multicolumn{8}{|l|}{ Employment } \\
\hline Employed & $115(31.7)$ & $15(40.5)$ & 1.69 & & & & 0.431 \\
\hline Unemployed & $133(36.6)$ & $10(27.0)$ & & & & & \\
\hline Student & $115(31.7)$ & $12(32.4)$ & & & & & \\
\hline \multicolumn{8}{|l|}{ Income } \\
\hline$\leq 50,000$ Yemeni Riyals & $268(90.2)$ & $29(9.8)$ & 3.29 & & & & 0.193 \\
\hline $51,000-100,000$ Yemeni Riyals & $51(87.9)$ & $7(12.1)$ & & & & & \\
\hline$>100,000$ Yemeni Riyals & $44(97.8)$ & $1(2.2)$ & & & & & \\
\hline \multicolumn{8}{|l|}{ Medical insurance } \\
\hline Yes & $55(96.5)$ & $2(3.5)$ & 2.61 & 3.125 & 0.730 & 13.370 & 0.106 \\
\hline No & $308(89.8)$ & $35(10.2)$ & & & & & \\
\hline \multirow{2}{*}{ Smoking } & $76(83.5)$ & $15(16.5)$ & 7.343 & 0.388 & 0.192 & 0.785 & 0.007 \\
\hline & $287(92.9)$ & $22(7.1)$ & & & & & \\
\hline Chewing khat & & & 5.696 & 0.294 & 0.102 & 0.850 & 0.017 \\
\hline Chewer & $257(88.6)$ & $33(11.4)$ & & & & & \\
\hline Non-chewer & $106(96.4)$ & $4(3.6)$ & & & & & \\
\hline Medical center & & & 7.191 & 2.688 & 1.275 & 5.666 & 0.007 \\
\hline Yes & $308(92.5)$ & $25(7.5)$ & & & & & \\
\hline No & $55(82.1)$ & $12(17.9)$ & & & & & \\
\hline \multicolumn{8}{|c|}{ Complications due to self-medication } \\
\hline Yes & $210(88.2)$ & $28(11.8)$ & 4.43 & 0.441 & 0.202 & 0.962 & 0.035 \\
\hline No & $153(94.4)$ & $9(5.6)$ & & & & & \\
\hline Death due to self-medication & & & & & & & 0.004 \\
\hline Yes & $164(86.3)$ & $26(13.7)$ & 8.48 & 0.349 & 0.167 & 0.727 & \\
\hline No & $199(94.8)$ & $11(5.2)$ & & & & & \\
\hline
\end{tabular}

In table 3 , multiple logistic regression was used to identify the most important risk factor related to self-medication. The results indicated that those who chewed khat were less likely to use selfmedication compared to those who did not chew khat (OR=0.296, CI $95 \% 0.100-0.882, p=0.029)$. Similar results showed that smokers were less likely to use self-medication compared to non-smokers $(\mathrm{OR}=0.429$, CI 95\% 0.206-0.895, $p=0.024)$. It was also found that those who have medical services near their residence were more likely to use self-medication compared to those who do not have medical services near their residence $(\mathrm{OR}=3.022$, CI 95\% 1.384 6.596, $p=0.006$ ). Moreover, those who did not believe that selfmedication leads to death were more likely to use self-medication compared to those who believed that self-medication may leads to death $(\mathrm{OR}=2.645$, CI 95\% 1.232-5.681, $p=0.013)$.

Table 3: Multivariate analysis (multiple logistic regression model)

\begin{tabular}{|c|c|c|c|c|c|c|c|}
\hline \multirow[t]{2}{*}{ Variables } & \multirow[b]{2}{*}{ B } & \multirow[b]{2}{*}{ S. E. } & \multirow[b]{2}{*}{ Wald } & \multirow[b]{2}{*}{ Sig. } & \multirow[b]{2}{*}{$\operatorname{Exp}(B)$} & \multicolumn{2}{|c|}{ 95\% C. I for EXP(B) } \\
\hline & & & & & & Lower & Upper \\
\hline Chewing khat & 1147 & 0.565 & 4.119 & 0.042 & 3.150 & 1.040 & 9.542 \\
\hline Smoking & 0.815 & 0.383 & 4.523 & 0.033 & 2.259 & 1.066 & 4.788 \\
\hline Medical Center & -1.115 & 0.406 & 7.531 & 0.006 & 0.328 & 0.148 & 0.727 \\
\hline Death due to self-medication & 0.973 & 0.390 & 6.224 & 0.013 & 2.645 & 1.232 & 5.681 \\
\hline Medical Insurance & -1.309 & 0.786 & 2.777 & 0.096 & 0.270 & 0.058 & 1.259 \\
\hline Monthly income & & & 3.510 & 0.173 & & & \\
\hline Constant & -4.535 & 1.212 & 14.014 & 0.001 & 0.011 & & \\
\hline
\end{tabular}

\section{DISCUSSION}

The prevalence of self-medication practice in different countries was ranged from $39 \%$ to $94 \%$ [17-25]. The prevalence in this study was $90.7 \%$ which suggests that self-medication practice in Sana'a city is among the highest. The reason for such variation may be due to the differences in socio-economic status, education, culture and healthcare system $[20,22]$. The most commonly medication used during self-medication were the analgesics which were found to be the main medication used according to many studies [20-23, 26].

Following analgesics, antibiotics were the second common medication used during self-medication. Although antibiotics use was reported to range from $32.7 \%$ to $46 \%[21,23,25]$ by other 
researchers, it is worth mentioning that $87 \%$ of respondents in this study used antibiotics. Such value indicates an inadequate drug regulation by health authorities. Other findings were consistent for medications used like antacids [20], vitamins [25, 26] and medications for common cold [20,21,25].

The respondents used self-medication mainly for the treatment of a headache, common cold, fever and acidity/ulcer. The findings were consistent with the results found for the type of medication used in fig. 1. Similar sort of illness was reported by other studies as well $[17,19,22]$. The most common reason for practicing self-medication was the high cost of physician consultation which was found to be the main reason for such practice in other studies [22, 27]. Other reason like illness was not serious and lack of time was found to be reported by other studies $[17,23,26]$.

The most common source of information during self-medication was the community drug dispenser which is similar to other studies [19, $22,23,25,26]$. This was expected as the pharmacy is the main supply for medication. Other sources like family member $[18,20,23]$ and media [21] were found to be common in other studies as well.

The bivariate analysis was used to identify the risk factors associated with self-medication as shown in table 2. Although some factors like gender and respondent perception about the complications due to self-medication and were significant, only chewing khat, smoking, the availability of medical services near residence and respondent perception about the possibility of death due to self-medication were found to be the most important factors in our study (table 3).

The result showed that female respondents were more involved in self-medication than males. It is commonly known that women in Yemen face various obstacles to health care and self-sufficiency which may be due to the cultural and religious history that influence their current state of health [28]. It is unlikely for a woman to leave her house without her parents, husband or guardian's permission. It is less common for a woman to visit a doctor unless the doctor is a women or condition is really serious. It was reported that only $36 \%$ of births are attended by doctors or skilled attendants [29]. Therefore, it may be favorable for a woman to visit the nearest pharmacy than visiting a doctor. The respondent perception about the complications due to self-medication was significant as well. Those who did not believe that self-medication leads to serious health complications were expected to be more involved in selfmedication practice due to their inability to recognize the risk and consequences.

Khat is a plant that is grown all over Yemen for centuries and more than $70 \%$ of the population are believed to use it [30]. It contains an alkaloid, cathinone, an amphetamine-like-stimulant believed to cause excitement, loss of appetite, and euphoria [31]. In the present study, those who did not chew khat were more likely to practice selfmedication compared to those who did chew khat. This can be due to the analgesic and antispasmodic effects of khat $[32,33]$. Other effects like feeling of well-being, increased level of energy and euphoria [34-37] may contribute to the reluctance of respondent toward self-medication practice.

Smokers were less likely to use self-medication compared to nonsmokers. Nicotine in cigarettes was found to produce pleasure, mood modulation [38, 39], induces stimulation and may improve concentration [40]. Moreover, cigarette additives were found to have some pharmacological effects. Such effects like anti-inflammatory and the possibility of influencing sexual behavior were believed to be used by the tobacco industry to mask symptoms and illnesses associated with smoking behavior [41]. Such effects and the feeling of well-being may be the reason behind the lack of enthusiasm of smokers towards self-medication practice.

It was also found that those who have medical services near their residence were more likely to use self-medication compared to those who do not have medical services near their residence. Such results were unexpected as those who live far from medical centers were more expected to use medication for self-treatment without referring to a physician. However, other reasons like the high cost of doctor consultation and the case were not serious maybe the reason for such results (fig. 2). Finally, those who did not believe that selfmedication leads to death had a similar attitude as those who did not believe that self-medication may lead to serious health complications. The respondents were expected to be more involved in such practice due to their inability to recognize the risk and consequences.

In developing countries like Yemen, poor quality of health care services, undeveloped health care infrastructures and the lack of comprehensive laws and regulations controlling medicine are among the reasons which encourage such practice and leads to an irresponsible use of medication. The high prevalence of selfmedication practice among consumers may be related to the fact that majority have a very low income with no access to medical insurance. In addition to the effect of chewing khat on selfmedication practice, it is of great importance to mention that Yemeni families have been reported to spend more than $60 \%$ of their income on khat [30].

Since community pharmacists were the main source of information/advice in this study, their role must be highlighted and closely regulated and controlled by health authorities. Moreover, the level of patient's understanding about their medications is highly variable and the need for professional guidance to select a suitable medicine for each condition was found to be increased [42, 43]. Furthermore, the perception of the respondents about self-medication in this study was found to affect their attitude toward such practice. This even suggests that consumers should have a basic knowledge about medication and health care to avoid any misuse of medication.

\section{Limitation of the study}

Although Sana'a is the capital and largest city in Yemen, a generalization of findings can be questioned. Translation equivalence was proposed by several researchers to be impossible. However, workable translation may be possible and demonstrable. Moreover, the original language will be open to revision if backtranslation is poor.

\section{CONCLUSION}

Self-medication practice was high among consumers in Sana'a City. Chewing khat, smoking, the availability of medical services near the residence and the respondent perception about the possibility of death due to self-medication was significantly associated with selfmedication. There is an urgent need to increase awareness and education among consumers for a safe and responsible practice. The role of community drug dispenser in self-medication should be investigated. A list of over the counter medications should be enforced by the health care authorities.

\section{ACKNOWLEDGMENT}

Special thanks to my supervisor and co-supervisors for their guidance and unlimited support. I would like to thank Prof. Dr. Sami Al-Dubai and Dr. Al-abed Ali for their valuable help in data analysis.

\section{CONFLICTS OF INTERESTS}

\section{Declared none}

\section{REFERENCES}

1. World Health Organization. Guidelines for the regulatory assessment of medicinal products for use in self-medication: WHO/EDM/QSM/00.1; 2000.

2. Galato D, Galafassi LDM, Alano GM, Trauthman SC. Responsible self-medication: a review of the process of pharmaceutical attendance. Braz J Pharm Sci 2009;45:625-33.

3. World Health Organization. The role of pharmacist in self-care and self-medication. The fourth consultative group meetings on the role of the pharmacist in the health care system organized by WHO in collaboration with the International Pharmaceutical Federation (FIP), Hague; 1998. p. 2-11.

4. Sarahroodi S, Arzi A, Sawalha A, Ashtarinezhad A. Antibiotic self-medication among Southern Iranian University students. Int J Pharmacol 2010;6:48-52. 
5. Martins AP, Miranda-Ada C, Mendes Z, Soares MA. Selfmedication in a portuguese urban population: a prevalence study. Pharmacoepidemiol Drug Saf 2002;11:409-14.

6. Jain S. Concept of self-medication: a review. Int J Pharm Biol Arch 2011;2:831-6.

7. Agbor MA, Azodo CC. Self-medication for oral health problems in Cameroon. Int Dent J 2011;61:204-9.

8. Rodriguez-Benito U, Magro-Peteguer R, Masip-Lopez M, Vacas Gamido R, Urbano-Rodriguez B. Self-medication in general paediatrics. Atención Primaria 1994;13:313-6.

9. Afolabi AO. Factors influencing the pattern of self-medication in an Nigerian adult population. Annu Afr Med 2008;7:120-7.

10. Casner PR, Guerra LG. Purchasing prescription medication in Mexico without prescription: the experience at the border. West J Med 1992;156:512-6.

11. Antonov K, Isaacson D. Use of analgesics in sweden. The importance of sociodemographic factors, physical fitness, health and health-related factors, and working condition. Soc Sci Med 1996;42:1473-81.

12. Pucynski MS, Gonzalez J, O'Keefe JP. Self-treatment with antibiotics. Soc Sci Med 1989;28:905-15.

13. Mohanna M. Self-medication with antibiotic in children in Sana'a city, Yemen. Oman Med J 2010;25:41-3.

14. Abdo-Rabbo A. Household survey of the treatment of malaria in Hajjah, Yemen. East Mediterr Health J 2003;9:600-6.

15. Bahaj AA. Prevalence of self-medication in Hadhramout Governorate. Tikrit J Pharm Sci 2006;2:810-26.

16. IBM Corp. IBM SPSS Statistics for Windows, Version 21.0. Armonk, NY: IBM Corp; 2008.

17. Suleman S, Ketsela A, Mekonnen Z. Assessment of self-medication practices in assendabo town, jimma zone, southwestern Ethiopia. Res Social Administrative Pharm 2009;5:76-81.

18. Marak A, Borah M, Bhattacharyya H, Talukdar KA. A crosssectional study on self-medication practices among the rural population of Meghalaya. Int J Med Sci Public Health 2016;5:1134-8.

19. Gupsta P, Bobhate P, Shrivastava SR. Determinants of selfmedication practices in an urban slum community. Asian J Pharm Clin Res 2011;4:54-7.

20. Ali LJ, Taqua AF, Salam ST. Self-medication practice among iraqi patients in Baghdad city. Am J Pharm Sci 2014;2:18-23.

21. Keshari SS, Kesarwani P, Mishra M. Prevalence and pattern of self-medication practices in the rural area of Barabanki. Indian J Clin Pract 2015;25:636-9.

22. Phalke V, Phalke D, Durgawale P. Self-medication practices in rural Maharashtra. Indian J Commun Med 2006;31:34-5.

23. Albalawi AH, AlAnazi BD, Althmali KA, Alzhahrani OM, Aloqbi HS. A descriptive study of self-medication practices among patients in a public health care system in Tabuk City. Int J Academic Sci Res 2015;3:127-33.

24. Kumar V, Mangal A, Yadav G, Raut D, Singh S. Prevalence and pattern of self-medication practices in an urban area of Delhi, India. Med J DY Patil Univ 2015;8:16-20.
25. AlFlaiti M, AlBadi K, Hakami WO, Khan SA. Evaluation of selfmedication practices in acute diseases among university students in Oman. J Acute Disease 2014;12:249-52.

26. Eticha T, Mesfin K. Self-medication practices in mekelle, Ethiopia. PLoS One 2014;9:e97464.

27. Kulkarni PK, Khan M, Chandrasekhar A. Self-medication practices among urban slum dwellers in South Indian city. Int J Pharm Biol Sci 2012;3:81-7.

28. Smithson RK. Women's health in yemen: factors influencing maternal and infant health, fertility rates, the public health care system, education, and globalization. J Global Health Perspectives 2012;1-7.

29. UNICEF, 'Yemen: MENA gender equality profile'; 2011c.

30. Basunaid S, Van DM, Cleophas TJ. Khat abuse in Yemen: a population-based survey. Clin Res Regul Affairs 2008;25:87-92.

31. Kalix P. Khat: a plant with amphetamine effects. J Substance Abuse Treatment 1988;5:163-9.

32. Eyassu M. Constipating and spasmolytic effects of khat (Catha edulis Forsk) in experimental animals. Phytomedicine 2000;74:309-12.

33. Connor J, Makonnen E, Rostom A. Comparison of analgesic effects of khat (catha edulis forsk) extract, d-amphetamine, and ibuprofen in mice. J Pharm Pharmacol 2000;52:107-10.

34. Carvalho F. The toxicological potential of khat. J Ethnopharmacol 2003;87:1-2.

35. Nencini P, Ahmed AM. Khat consumption: a pharmacological review. Drug Alcohol Depend 1989;23:19-29.

36. Nencini P, Ahmed AM, Amiconi G, Elmi AS. Tolerance develops to sympathetic effects of khat in humans. Pharmacology 1984;28:150-4.

37. Widler P, Mathys K, Brenneisen R, Kalix P, Fisch HU. Pharmacodynamics and pharmacokinetics of khat: a controlled study. Clin Pharmacol Ther 1994;55:556-62.

38. Jiloha RC. Biological basis of tobacco addiction: implications for smoking-cessation treatment. Indian J Psychiatry 2010;52:301-7.

39. Henningfield JE, Miyasato K, Jasinski DR. Abuse liability and pharmacodynamic characteristics of intravenous and inhaled nicotine. J Pharmacol Exp Ther 1985;234:1-12.

40. Benowitz NL. Pharmacology of nicotine: addiction, smokinginduced disease, and therapeutics. Annu Rev Pharmacol Toxicol 2009;49:57-71.

41. Rabinoff M, Caskey N, Rissling A, Park C. Pharmacological and chemical effects of cigarette additives. Am J Public Health 2007;97:1981-91

42. Bissell P, Ward PR, Noyce PR. The dependent consumer: reflections on accounts of the risks of non-prescription medicines. Health 2001;5:5-30.

43. Hughes L, Whittlesea C, Luscombe D. Patients' knowledge and perceptions of the side-effects of OTC medication. J Clin Pharm Ther 2002;27:243-8.

\section{How to cite this article}

- $\quad$ Sami Mohammed Albawani, Yahaya Bin Hassan, Noorizan AbdAziz, Shubashini Ganesan. Self-medication practice among consumers in Sana'a city. Int J Pharm Pharm Sci 2016;8(10):119-124. 